Original Research Article

\title{
Big Book: Attractive Media for Teaching Vocabulary to Lower Class of Young Learners
}

Anissa Indrasari ${ }^{*}$ (D), Dian Novita ${ }^{2}$ (D), Fika Megawati ${ }^{3}$

${ }^{1,2,3}$ Fakultas Keguruan dan Ilmu Pendidikan, Universitas Muhammadiyah Sidoarjo, Jl. Majapahit 666B, Sidoarjo, East Java, Indonesia, 61215.

Article History:

Submitted : $2^{\text {nd }}$ August 2018, Accepted: $27^{\text {th }}$ September 2018, Published : $15^{\text {th }}$ October 2018

\begin{abstract}
Introducing English to young learners is challenging job. In order to make the students focus, something interesting should be brought inside the classroom. One of the media that can potentially entertain students as well as transfer the language concept is big book. The aim of this study is to find out whether there is significant effect in students' vocabulary achievement in the first grade at primary school before and after being taught by using big book. In this case, the researchers used quantitative method with quasi experimental design. The subject of this research consisted of 35 students in each group. The main activities conducted in the learning process were try-out, pre-test, treatment and post-test. In analyzing, the researcher used ttest to calculate the data and to test the hypothesis. The result of this research revealed that the use of big book gives significant effect to students' vocabulary achievement. Further, the result of vocabulary recognition task or VRT in I-B as experimental class showed more satisfying point. This implies that teachers for young learners have to be active and creative to present attractive media so that the learners can be motivated in learning the target language, especially in the context of EFL.
\end{abstract}

\section{Keywords: big book; teaching vocabulary; young learners.}

HOW TO CITE: Indrasari, A., Novita, D., Megawati, F. (2018). Big Book: Attractive Media for Teaching Vocabulary to Lower Class of Young Learners. JEES (Journal of English Educators Society), 3 (2), 141-154. doi: https://doi.org/10.21070/jees.v3i2.1572

\section{Introduction}

Based on Curriculum 2013 or K-13 English becomes a local content subject in primary school, but it still taught because English as an international language and it is important for children. Vocabulary is one of important things in English teaching and learning process. Moreover, learning English vocabulary is continued process that needs systematic repetition to

*Coresponding author.

E-mail address: anissaindrasari0@gmail.com

Peer reviewed under reponsibility of Universitas Muhammadiyah Sidoarjo.

(C) 2018 Universitas Muhammadiyah Sidoarjo, All right reserved, This is an open access article under

the CC BY license (http://creativecommons.org/licenses/by/4.0/) 
motivate young learners for their English learning. It means that students especially young learners need extra time to know and understand with English vocabulary.

Vocabulary is the basis for how well learners in four language skill such as listening, writing, reading, and speaking (Renandya \& Richards, 2002). In the other hand, vocabulary is large collection of words (Thornburry, 2002). Beside the other aspects, vocabulary plays an important role in language teaching and learning. Learners can success in their ability in their academic and social with learn various of new words in a new language (Novita, 2014). Learners need to understand, know and familiar how they relate one word and the others when they make sentence or make dialogue to communicate. Vocabulary supports for the students to understand the language easily. If the students especially young learners want to become competent in English, they must familiar and learn many English vocabulary.

The aim of testing vocabulary is to find out student's level of achievement tests at the end of the course. Testing vocabulary is one of a form of feedback effect between teachers and their learners (Thornburry, 2002). If the teachers give vocabulary test to their students, it can motivate their students to review their knowledge about vocabulary in preparation for a test. There are many ways to test student's vocabulary achievement (Stahl, Dougherty, Bravo, \& A, 2010). There are three classrooms vocabulary assessment. The first is vocabulary knowledge scale or VKS; the second is vocabulary recognition task or VRT; the last is vocabulary assessment magazine or VAM. In addition, there are four assessment' vocabulary knowledge oral reading assessment, cloze test, maze test, and vocabulary flash cards.

Vocabulary Knowledge Scale or VKS is the vocabulary assessment that combines the students' self-reported knowledge with a concept response to show their knowledge to target word. In Vocabulary Recognition Task or VRT, the teachers give some words based on the topic that their given to their students. The students only put a circle around the words that they know, understand or remind. Vocabulary Assessment Magazine or VAM is the vocabulary assessment used by the teachers or educators to calculate the students' science knowledge, their strategy to understand the words and meaning in English vocabulary, and also their reading comprehension of science texts.

In the other hand, there are four assessments vocabulary knowledge that can used by the teachers or educators. The first is oral reading assessment. In this assessment, the teachers or educators can assess their students' vocabulary knowledge with read text loudly. The second is 
cloze test. In cloze test, the leaners guess the missing words based on their knowledge about subject, their understanding about basic of syntax, and meaning of words or sentence.

The third is maze test. The aim and the format of maze test is like cloze test. The difference, in maze test the learners given three choices to answer based on their understanding. If the learners make many errors in this assessment, it can be conclude that the learners need more guidance for their teachers or educators. The last is vocabulary flash cards. This assessment is one of traditional ways to measure students' vocabulary quickly. The students only have five seconds to identify each word that given by their teachers or educators.

Teaching vocabulary to young learners will be more effectively if it has relation with their environments. Teachers or educators need preparation to teach young learners (Cameron, 2001). Students in primary school or young learners cannot repeat new vocabulary in short time. It means that the teachers should make connection between vocabulary with the students' lives through their environments, so they can learn and remind vocabulary easily. Several general principles can be implemented by teachers or educators to young learners such as using suitable model and strategies to get students' attention. The teachers or educators should use appropriate technique and choose suitable method to teach vocabulary for their students especially young learners.

Young learners aged between five until twelve years old (Cameron, 2001). Children are the first stage in language teaching and learning process. Children can increase their language skill if they have many vocabularies. Teaching children is not easy and very different with teaching adults. Young learners learn from all things around them, they cannot understand only from explanation and they easily to get bored. Teachers or educators of young learners can give something which can take their interest and concentration such as fun activities, interesting media.

Children and adults have different characteristics (Brown, 2001). The differences between them divided into five aspects. In intellectual development aspects, children up to the eleven years have concrete operations process. They need several times to remind something than adults. Children have high natural curiosity than adults. It calls attention span aspects. The next aspects is sensory input. Children is very sensitive for facial features and gesture. They like touching something. In affective factors, sometimes children get potential barriers easily when they learn something. The teachers or educators need to help them when they ae 
in that situation. The last is authentic meaningful. In this aspect, children learn language easily than adults because they are good at sense of language.

Media is one of something that can deliver the information between source and receiver. In teaching and learning process, there are three kinds of media. They are visual, audio and video. One of media that the teachers can use is big book. Big book is one of alternative interesting media that can use teachers or educators of young learners. Big size is one of characteristics of big book (O’Connor, Barbar, Coville-Hall, \& Susan, 2006). Big book is a book which contains big pictures, words or sentences and colorful. The students in a class can see all part of the big book because the size of book is different from the ordinary books. Big book is appropriate for preschoolers and for students in primary school (Santi, Asteria, Regina, \& Fergina, 2016).

In the other hand, the good big book must have six characteristics (O'Connor et al., 2006). The first, big book is short stories. The second, it contains a rhyme pattern. The third, big book has big pictures. The fourth, big book must have repetitive phrases and familiar vocabulary for young learners. The fifth, it is simple but interesting. The last, big book contains about humor elements. It is important thing because children get bored easily so the teachers must make fun atmosphere in language teaching and learning process. Big book has large print and colorful words, sentences or pictures. It can allow whole students in classroom when the teachers give material for their students. In addition, when the teachers using big book in teaching and learning process, they can catch the student's interest and concentration. The abnormal size from big book help students to give their attention and focus in English teaching and learning process.

There are three related studies relevant to this research. the previous study conducted by (Fahmi et al., 2015; O'Connor et al., 2006; Santi et al., 2016). They found that big book was effective media and having significant effect also to improve the students' vocabulary achievement. Big book makes young learners learn vocabulary more effective and better than normal size book. It is also recommended to use in teaching and learning process. This media can catch the students' attention, the students can read it by themselves or the teachers read it aloud in front of their students.

The researchers put their interest to conduct this study because vocabulary is very important thing in language teaching and learning process. Young learners ae the first stage 
in learning language process. They must know and get familiar with vocabulary to increase their language skill. Learning vocabulary needs systematic repetition to support young learners for their language learning so the need extra time to know and to be familiar with vocabulary. Teaching young learners is not easy and very different with teaching adults. Teachers of young learners can give young learners fun activities, inteseting media or anything that can take their interest and concentration. Big book is one of interesting media for young learners. Big book can help teachers to give materials for their students easily and make fun class' atmosphere. Large print with colorful words, sentences or pictures can allow class which has whole students to deliver materials from the teachers. Young learners can see the enlarge format of big book while it read by their teacher or themselves and being pointed.

\section{Methods}

This research was conducted in the first grade students at SDN Pepelegi 1 WaruSidoarjo in academic year 2017/2018. It started from January $8^{\text {th }}, 2018-$ February $7^{\text {th }}, 2018$. The researcher concluded that students in the first grade need something to help them for catch and understand the material easily from their English teacher. The researcher explains that the result of test which has done by two groups, experimental and control class.

The first grade students were given pre-test to measure and know the original of students' vocabulary achievement before they get treatment using big book. After they did pre-test, the students in I-B used big book as a treatment, but I-A did not use big book. The researcher gave post-test after the students had the treatment. Post-test used to measure and to know students vocabulary achievement after they get treatment.

There are five steps to use big book in teaching and learning process (O'Connor et al., 2006). The first, the teacher asks to the students to look at the book cover illustration and asks to the students to predict the story based on the title. The second, the teacher reads aloud the story and asks to the students to choose their favorite parts or characters. The third, the teacher asks to one of the student to read story aloud and use their pointer to indicate the new words. The fourth, the teacher asks to the students to reread individually. The last, the teacher also give other activities to engage their students such as retelling the story with different ending or making a class book or individually book based on the story.

In the other hand, big book guidelines for reading aloud divided into two (Megawati \& Wulandari, 2017). They are before reading and during reading aloud. In the before 
reading, there are six steps. The first, teacher greets their students and explain why the teacher uses big book in this section. The second, the teacher shows the cover and give little summary from the big book. The third, the teacher tells the title, author and illustrator from the big book. The fourth, the teacher explores the students' in reading book. The fifth, the teacher starts tracking the illustration of the big book. The last, the students read the big book in front of the other students.

In the during aloud, there are seven steps. The first step, the teacher gives voice, intonation clearly, expression and suitable gesture. The second step, the teacher must be friendly. The third step, the teachers gives respond about the students' comment and question. The fourth step, the teacher asks to their students to focus on the material. The fifth, the teacher shares information and discusses during reading the book. The last step, the teacher encourages the students to ask something and retell the story briefly.

The researcher used several form in the pre-test and post-test such as write letter, draw line, circle the correct word and correct picture. This research used quantitative method and used true experimental as research design. There are two characteristics of true experimental. The first, there is control group (Sugiyono, 2017). The second, the sample is dawn randomly. The limitation of this research is the first grade students of SDN Pepelegi 1 Waru-Sidoarjo. The scope of this research that the big book contains four topics such as personal identity, greetings \& partings, alphabet, and colors.

Population is generalization that has subject or object who has specify quality or characteristics (Sugiyono, 2017). Something that can called population is not only human but also object and the other things. In this research, the researcher took all of the first grade students of SDN Pepelegi 1 Waru-Sidoarjo as the population. The number of population is 88 students that divided into three classes. Sample is amount unit and characteristics of the population (Sugiyono, 2017). From teacher's recommendation of the English teacher, the sample of this research were I-B as experimental group and I-A as control group. Each group consist of 35 students. The researcher gave big book as treatment in teaching and learning process for experimental class. For the control class, the English teacher did not gave big book in teaching and learning process. The English teacher only gave explanation about the material and used students' worksheet in English teaching and learning process. 
The researcher used pre-test and post-test to know about how the far students' vocabulary achievement before and after the treatment. There are 20 questions which formulated for pretest and post-test. It consists of write letter, draw a line, make a circle the correct picture and the correct word. Before the test items assessed to the first grade students, the researcher measure the validity. Valid instrument is instrument that can used to measure something should be measured (Sugiyono, 2010). Validity divided into two types. They are construct and content validity. In this research, the researcher used content validity. Content validity done by comparing the content of instrument and subject material has received by the students. It can be conclude that the test must appropriate with the students' material that have been they learned.

In this study, the researchers had done trial to the students in the different class. In the trial process, the researcher prepared 40 questions. From the students' answer, the researcher calculated the data. In calculating the data to find the validity, the researcher used The Product Moment Correlation Formula (Sugiyono, 2015). The formula is as follows:

$$
\mathrm{r}=\frac{n \Sigma X_{i} Y_{i}-\left(\Sigma X_{i}\right)\left(\Sigma Y_{i}\right)}{\sqrt{\left[n \Sigma X_{i}^{2}-\left(\Sigma Y_{i}\right)^{2}\right]\left[n \Sigma Y_{i}-\left(\Sigma Y_{i}\right)^{2}\right]}}
$$

Where:

- $r$ : coefficient or correlation between variable $X$ and $Y$.

- $\mathrm{X}$ : sum of score in $\mathrm{X}$ distribution.

- $Y$ : sum of score in $Y$ distribution.

- $\mathrm{X}^{2}$ : sum of $X$ quadrate.

- $\mathrm{Y}^{2}$ : sum of Y quadrate.

- $\mathrm{n}$ : sum of sample.

After 40 items questions analyzed, there were 39 valid and 1 invalid question. From the result, the researcher only chosen 20 questions for pre-test and post-test.

Reliability means the instrument can be used several times to measure the same object and produce the same data (Sugiyono, 2010). There are four kinds of reliability. They are testretest (stability), equivalent, mixed test-retest and equivalent, and internal consistency. This research used internal consistency technique. The instrument tested in only one time (Sugiyono, 2017). 
The Spearman Brown Formula is as follows:

$$
r_{i}=\frac{2 \cdot r_{b}}{1+r_{b}}
$$

Where:

- $r_{i}$ : internal reliability of all instrument.

- $\mathrm{r}_{\mathrm{h}}$ : product moment correlation between the first and second parts.

The criteria of coefficient correlation is as follows (Sugiyono, 2017):

\begin{tabular}{|c|c|}
\hline Interval Coefficient & Level \\
\hline $0,00-0,199$ & Very low \\
\hline $0,20-0,399$ & Low \\
\hline $0,40-0,599$ & Middle \\
\hline $0,60-0,799$ & High \\
\hline $0,80-1,000$ & Very high \\
\hline
\end{tabular}

The result of the reliability in this research was 0.88 . Based on the interval coefficient which number $0.80-1.00$ was included in very high level. It can be conclude that the validity instrument was reliable.

The instrument used in this research was a test. The purpose of using test was to know whether using big book make students remind and understand English vocabulary easily. There are two types of the test in this research. There are pre-test and post-test. The researcher used pre-test and post-test to compare the students' vocabulary achievement. The pre-test and posttest contains 20 questions. The pre-test and post-test formulated in the several forms. They are write letter, draw line, circle the correct word and picture.. The score was 1 for the right, but 0 for the wrong answer.

The formula to calculate the total score used:

$$
S=\frac{R}{n} X 100
$$


Where:

- S: score

- $\mathrm{R}$ : total number of right score

- $\mathrm{n}$ : total number of items

The table of criteria student's score

\begin{tabular}{|c|c|c|}
\hline Predicate & Score & Qualification \\
\hline A & $92-100$ & Excellent \\
\hline B & $83-91$ & Good \\
\hline C & $75-82$ & Enough \\
\hline D & $<74$ & Need guidance \\
\hline
\end{tabular}

In this research, the researcher used pre-test and post-test to conduct the data collection. The researcher calculated the result of pre-test and post-test with t-test formula (Sugiyono, 2015):

$$
t=\frac{\bar{x}_{1} \bar{x}_{2}}{\sqrt{\frac{\Sigma x^{2}+\Sigma y^{2}}{n_{1} n_{2}-2}\left(\frac{1}{n_{1}}+\frac{1}{n_{2}}\right)}}
$$

Where:

- $\mathrm{t}$ : coefficient of t-test.

- $\bar{x}_{1}$ : mean of experimental class.

- $\bar{x}_{2}:$ mean of control class.

- $\Sigma x^{2}:$ deviation of experimental class.

- $\Sigma y^{2}:$ deviation of control class.

- $\mathrm{n}_{1}$ : the total of data of random experimental class.

- $\mathrm{n}_{2}$ : the total of data of random control class.

There are two hypothesis in this research. There is no significant effect using big book in students' vocabulary achievement of first grade at SDN Pepelegi 1 Waru-Sidoarjo as the null hypothesis. For the alternative hypothesis, there is significant effect of using big book in students' vocabulary achievement of first grade at SDN Pepelegi 1 Waru-Sidoarjo.

The formulated for the hypothesis statistic is as follows:

$\mathrm{H}_{0}: \mathrm{t}_{\text {value }}$ is lower than $\mathrm{t}_{\text {table }}$

$\mathrm{H}_{\mathrm{a}}: \mathrm{t}_{\mathrm{value}}$ is higher than $\mathrm{t}_{\text {table }}$ 
The researcher used vocabulary recognition task or VRT to calculate the student's vocabulary achievement (Stahl et al., 2010).

From the students' answer, the researcher can know their students' vocabulary achievement with formula:

$$
\mathrm{P}(\mathrm{K})=\mathrm{P}(\mathrm{H})-\mathrm{P}(\mathrm{FA}) / 1-\mathrm{P}(\mathrm{FA})
$$

Where:

- H or hit: correctly words.

- FA or false alarm: incorrectly words.

There are three categories to analyze the student's vocabulary achievement. The categories are:

- A: Classroom score calculation $(\mathrm{H}-\mathrm{FA}=\mathrm{K})$

- B: Classroom score calculation (Percentage of correct choices $=\mathrm{K}$ )

- $\quad \mathrm{C}$ : Proportion $(\mathrm{P})$ known calculation $[\mathrm{P}(\mathrm{H})-\mathrm{P}(\mathrm{FA}) / 1-\mathrm{P}(\mathrm{FA})=(\mathrm{K})]$

After the researcher calculate the score of student's vocabulary achievement, the researcher analyzed with some criteria based on maze test. From the result of students' vocabulary test, the researcher classified them into three categories. The scoring criteria in this test is:

\begin{tabular}{|l|c|}
\hline \multicolumn{1}{|c|}{ Level } & Criteria \\
\hline Independent & $50 \%$ or more correct \\
\hline Instructional & $33-49 \%$ correct \\
\hline Frustration & $0-32 \%$ correct \\
\hline
\end{tabular}

\section{Findings and Discussion}

The result of the pre-test was given on January $8^{\text {th }}, 2018$ in I-B was 73.83 and on January $10^{\text {th }}, 2018$ was 77.34 . The result of the post-test score that was given on January $29^{\text {th }}, 2018$ for I-B was 86.88 and on January $31^{\text {st }}, 2018$ for I-A was 82.58. After giving the result of pretest and post-test in the I-B as experimental class and I-A as control class, the researcher analyze them by using t-test to find out whether there is significant effect between students' vocabulary achievement before and after being taught using big book. 
There are four steps to analyze the data such as finding means of the control and experimental class, finding deviation of the experimental and control class, inserting data into the t-test, and finding the degree of freedom. The means result of experimental was 17.14 and the control class was 7.29. The deviation of experimental class was 19664.29 and the control class was 18767.14 . The result of t-test was 2.840 and the degree freedom was 68 . Based on the significance was $5 \%(0.05)$ and the degree of freedom result was 68 , they derived table $=$ 1.995 and test $=2.840$. it can be conclude that t-test is higher than t-table. So, there is a significant effect of using big book in vocabulary achievement of first grade at SDN Pepelegi 1 Waru- Sidoarjo.

The result of vocabulary recognition task or VRT in I-B as experimental class, there are only three students who categorized instructional. In I-A as control class, there are three students who categorized instructional and one student categorized frustration. The highest score in I-B as experimental class is $100 \%$ and the lowest is $33.33 \%$. in I-A as control class, the highest score is $100 \%$ an the lowest is $20 \%$. It means that big book give positive effect and can increase student's vocabulary achievement.

The findings of this research showed that big book is an effective media in students' vocabulary achievement. This research applied in the some steps. The first step, the students in experimental and control class did pre-test. The second step, the researcher used big book as a treatment in I-B. The researcher also gave some worksheet for the students based on the topics. After whole activity, the students did post-test. The result of this research was correlated with the previous study conducted by (Fahmi et al., 2015; O'Connor et al., 2006; Santi et al., 2016). Fahmi, Indah, Suhartono, Luwandi, \& Arifin, (2015) studied about the improvement reading comprehension with big book trough classroom action research. The result shows that the students reading comprehension was improved when big book was applied as the media in teaching and learning process. O'Connor et al., (2006) also conducted the study about big book. The participants were the teachers. The result indicated that big book brings positively effect in language teaching and learning process. Big book project also make positive progress for the teachers in their skill to teach young learners. The last study, Santi et al., (2016) used preexperimental research design. The participant of this study was PAUD students. The result explains that using big book give high positive effect in teaching vocabulary, big book can build interaction between teacher and students in language teaching and learning process and using big book makes children learn vocabulary better than normal size book. 


\section{Conclusions}

The researcher conclude that there is significant effect of using big book in vocabulary achievement of first grade at SDN Pepelegi 1 Waru- Sidoarjo. Big book gives high positive effect in teaching vocabulary for young learners. It can be showed from the result of the students' categorize vocabulary achievement in experimental class if most of the students in the level of independent and only three students in the level of instructional. It can be conclude that using big book in teaching vocabulary for young learners can increase their vocabulary achievement.

Using big book in English teaching and learning process assists students to memorize vocabulary easily. If the teachers or educators want to use big book in their teaching and learning process, they do not have to buy it. Big book can be designed and created based on the teachers or educators creativity, or based on the students' need. Big book also could help the teachers especially English teacher to deliver the materials for their students. It can help the teachers to make fun atmosphere in English teaching and learning process and to motivate their students to understand and familiar with English vocabulary. Build interaction between the teachers and their students in English teaching and learning process is another advantage of big book implementation. Thus, the researchers suggested and supported the future researchers to enrich the media in teaching vocabulary for young learners.

\section{Acknowledgments}

The researcher realizes that this research can never finish without help of the others during the process of writing. The researcher would like to express gratitude and appreciation to the: the head of English Language Education Study Program and as the examiner board members; the English teacher of SDN Pepelegi 1 Waru-Sidoarjo and all students in SDN Pepelegi 1 Waru-Sidoarjo especially students of I-B grade.

\section{References}

Brown, H. D. (2001). Teaching by Principles : An Interactive Approach to Language Pedagogy. New York: Longman.

Cameron, L. (2001). Teaching Languages to Young Learners. UK: Cambridge University Press. 
Original Research Article

Big Book: Attractive Media for Teaching Vocabulary to Lower Class of Young Learners

Anissa Indrasari, Dian Novita, Fika Megawati

Fahmi, Indah, D., Suhartono, Luwandi, \& Arifin, Z. (2015). Improving Student' Reading Comprehension Using Big Book, 1-11.

Megawati, F., \& Wulandari, F. (2017). Promoting Big Book and Reading Corner to Support Gerakan Literasi Sekolah (GLS) in Primay School. In Desain Pembelajaran di Era ASEAN ECONOMIC COMMUNITY (AEC) Untuk Pendidikan Indonesia Berkemajuan (pp. 11-19).

Novita, D. (2014). The Use of Morphemes: An Alternative Way to Increase The Mastery of Students' Vocabulary.

O’Connor, Barbar, Coville-Hall, \& Susan. (2006). Using Big Books: A Standards-Based Instructional Approach for Foreign Language teacher Candidates in a PreK-12 Program, 39(3), 487-506.

Renandya, W. A., \& Richards, J. C. (2002). Methodology in Language Teaching. New York: Cambridge University Press.

Santi, Asteria, Regina, \& Fergina, A. (2016). Teaching Vocabulary Through Big Book to Students of PAUD Santa Maria Ratu Rosari. Pontianak, Indonesia: Tanjungpura University.

Stahl, Dougherty, K. A., Bravo, \& A, M. (2010). Contemporary Classroom Vocabulary Assessment for Content Areas. In International Reading Association (pp. 566-578).

Sugiyono. (2010). Metode Penelitian Pendidikan: Pendekatan Kuantitaif, Kualitatif, dan $R \& D$. Bandung, Indonesia: Alfabeta.

Sugiyono. (2015). Statistika untuk Penelitian. Bandung, Indonesia: Alfabeta.

Sugiyono. (2017). Metode Penelitian Pendidikan: Pendekatan Kuantitaif, Kualitatif, dan $R \& D$. Bandung, Indonesia: Alfabeta.

Thornburry, S. (2002). How to Teach Vocabulary. England: Pearson Education Limited. 
